ISSN 2338-4778 (Print)

ISSN 2548-4192 (Online)

Volume 8, Number 1, June 2020

pp. $105-115$

\title{
Classroom Interaction in Teaching English for Mechanical Engineering Students
}

\author{
Dharmawati \\ dharmawati66@yahoo.com \\ Engineering and Computer Science Faculty, Universitas Harapan, Medan, Indonesia
}

Received: 26 April 2020 Accepted: 11 May 2020

DOI: $10.24256 /$ ideas.v8i1.1316

\begin{abstract}
This descriptive qualitative research deals with classroom interaction in teaching English for mechanical engineering students. This research aims at finding out and describing the classroom interaction of mechanical engineering class at Universitas Harapan Medan. The purpose of this study is to figure out the patterns of classroom interaction in English teaching learning process for mechanical engineering class. The methods used in collecting data were observation and interview. The data were in the form of words, clauses, and sentences that carried out by video, and in-depth interview transcripts. The participants were an English lecturer and twenty two mechanical engineering students. The technique of data analysis used data collection, data diplay and drawing conclusion. The result of this research was dominated by the interaction between the teacher and students. The percentage of using English between lecturer and students' interaction is $40 \%$. It happened because the students had difficult to respon the lecturer's question in English.
\end{abstract}

Keywords: classroom Interaction; interaction pattern, mechanical engineering.

\section{Introduction}

Classroom interaction has been an important issue in teaching and learning English in the era of communicative language teaching. Interaction in a classroom covers communication of the teaching learning process defined as classroom interaction. Classroom interaction is significant in the teaching and learning process because it determines the success of the teaching and learning process and improves students' English language ability and achievement. Goronga (2013) asserts that the classroom interaction makes the students participating in the teaching and learning process. It means that classroom interaction encourages the students to involve. What's more, classroom interaction is not only about participation in the teaching and learning process and sharing their knowledge of a 


\section{Dharmawati}

Classroom Interaction In Teaching English For Mechanical Engineering Students

material at each other, but it is also about a relationship at each student to other students in the classroom. Classroom interaction exchange is the kinds of the utterance that the teacher and students talk in the classroom (Fibri, 2018).

The interaction in the university also is carried out by parts of the teaching and learning process such as materials, the teaching learning facilities and learning media, and environment surrounding. One of the classroom interaction happens in the English teaching-learning process at mechanical engineering class at Universitas Harapan Medan.

Classroom interaction in the English teaching-learning process of mechanical engineering class, interaction is one parts that support the students' learning achievements. It is generally known that interactions between a student and a lecturer, a lecturer and students, a student and students, students and materials influence students' learning and lecturers' teaching activities. When the interaction has in a high quality, the process of effective and efficient English teaching-learning will appear. Such an English teaching-learning process may support the quality of students' learning achievement especially for mechanical engineering students.

However, the interaction in a teaching English language for mechanical engineering is very complicated. Many problems appeared to develop teaching learning process through a communicative interaction because mechanical students get a difficulty in expressing themselves in using English language in the classroom. Therefore, the ways of lecturer both using English language and giving the students opportunity in developing their English language are very important to understand.

Some previous researches which are relevant to the present research had done before. Rini (2013) conducted the research about Classroom Interaction: An Analysis of Teacher Talk And Student Talk In English For Young Learners (Eyl). She investigated on 1) the realization of verbal classroom interaction, 2) types of teacher talk 3) teacher talk implication on student's motivation, 4) student talk and 5) teacher's roles in classroom interaction. It was a qualitative research and case study approach, the data for the research were collected in a classroom context where the participants were an English teacher for young learners and her 15 students. The results indicate that all of the teacher talk categories of FIAC were revealed covering giving direction, lecturing, asking questions, using student's ideas, praising, criticizing student's behavior and accepting feelings. The teacher mostly adopted a role as controller in the classroom as she frequently led the flow of interaction. In terms of student talk, student's response and initiation were revealed in this study. It is also found that student's initiation plays a significant part in the classroom interaction.

The next research was also conducted by Ansory (2018) about English Teachers' Perceived Benefits And Challenges Of Flipped Classroom Implementation. He was intended to explore the general responses of English teachers toward the flipped classroom methodology and investigate the perceived benefits and challenges of its implementation in English teaching. The results reveal that 
English teachers have positive responses to the flipped classroom methodology. Some perceived benefits of its implementation are facilitating active learning, developing collaborative teamwork, stimulating learning, and increasing classroom interaction. And the research from Rustandi and Mubarok (2017). They studied on classroom interaction in EFL speaking class at university sum up that IRF pattern is fully implemented in the class. Teacher initiates the interaction by giving questions, soliciting information, and identifying next students' turn.

The regulation of the Kementrian Pendidikan dan Kebudayaan number 23, 2016 about standard of assessment, learning is the process of interaction among students, between the students and the teachers and learning source in the learning environment. The regulation stated that interaction is needed in the teaching-learning process. Therefore, classroom interaction should be analyzed to get some reference in developing teaching English for mechanical engineering students. This research aims to address the following research questions:

1. How does classroom interaction take place in In teaching English for mechanical engineering students at at Universitas Harapan Medan.

2. What type of classroom interaction used in teaching English language to mechanical engineering students at Universitas Harapan Medan.

\section{Classroom Interaction}

Classroom interaction occurs both between students with lecturer present, and with the lecturer who explores student thinking among the whole groups. Classroom interaction can be called by a practice that improves the development skills among the students. Therefore, interactions do not occur from only one side, but also from two or more objects that through giving and receiving messages in order to achieve communication such as lecturer and students. Robinson (2005) notes interaction in the classroom is channeled through nonverbal interaction. There are many functions of non verbal interaction in the classroom, such as expressing emotion, communicating personal attitudes and supporting speech.

Allwright and Bailey (1991) stated that through classroom interaction, the plan produces outcomes (input, practice opportunities, and receptivity). The teacher has to plan what he intends to teach (syllabus, method, and atmosphere). So, the classroom interaction has important role in teachinglearning process. It can be seen from the figure below.

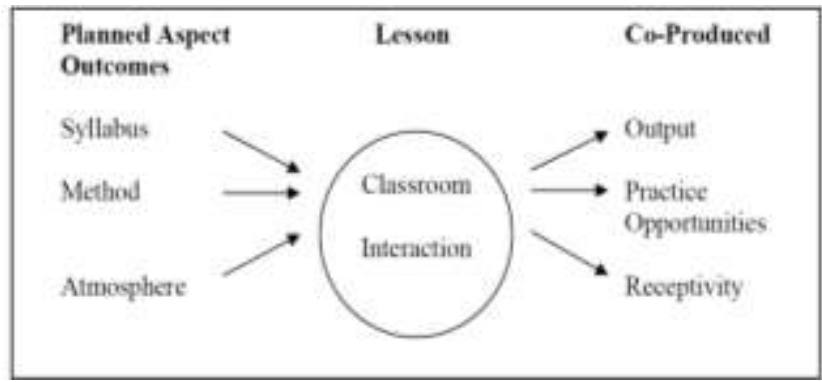

Figure 1. The relation between plans and outcomes 
The figure explains that a lecturer must be flexible. In teaching learningprocess the lecturer should not be too focus on the best method, the teacher should be looking for the most appropriate approach, design of materials, or set of procedures in having interaction. The lecturer should not be dominated, let the students become more active in their learning.

\section{Interaction Pattern}

Interaction is a two way process. Malamah (1991) states the pattern of interaction in the classroom as follows: (1) interaction between the teacher with the whole of class, (2) interaction between the teacher and a group of students, (3) interaction between the teacher and the individual student, (4) interaction between the student and the teacher, (5) interaction between the student and another single student, and (6) interaction between the student and a group of students. The pattern of classroom interaction as two-way a process between interaction in the teaching learning process is shown in Figure 2 (Rustandi \& Mubarok, 2017) depicted interaction in two way process between participants in the learning process as seen in Figure 2.

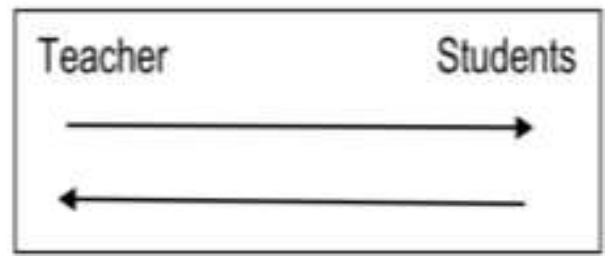

Figure 2 Classroom Interaction Pattern

The classroom interaction shows that the interaction must involve both the lecturer and students. There is action from lecturer and there must be reaction from students, both action and reaction can be drawn in the form of thoughts, ideas, and feelings, and suggestion.

This research was started by identifying problems and learning objectives and describing the types of classroom interaction, it meant that the researcher identified problems that exist on students, it was also regarded to object of learning students, particularly problems and object learning in classroom interaction was there feedback or not, after researcher found a solution that was essential for student that student had to active. The theoretical framework underlying this research was presented in the diagram below: 


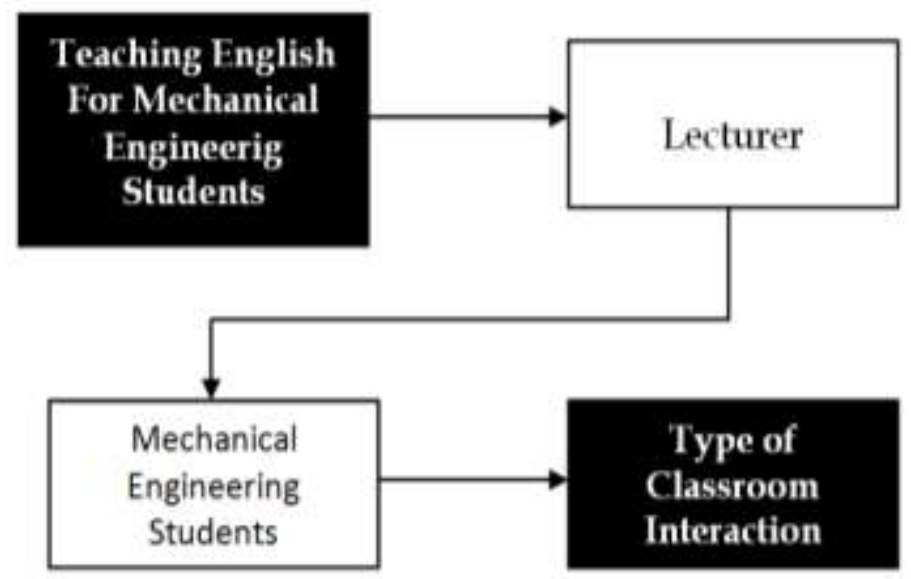

Figure 3. The theoretical framework

The theoretical framework explanations that the researcher analyzed the type of classroom interaction on teaching English to mechanical engineering students, there were two ways to know what type the use in classroom interaction such as lecturer and mechanical engineering students. The lecturer teaches English and gave some question in the classroom interaction. Mechanical engineering students gave the feedback during teaching ang learning in the classroom interaction.

Compared to these previous researches, this research tries to find out how classroom interaction takes place in teaching English for mechanical engineering students and to describe the type of classroom interaction used in teaching English language to mechanical engineering students at Universitas harapan Medan.

\section{Method}

The method used in this research was qualitative research. How the classroom interaction in teaching of English to Mechanical Engineering was conducted would be described in narration and description of the reasons underlying the performance was explained. There were interconnected steps used in the process of analyzing the data. The first step was to arrange and prepare the data for analysis. This involved observing the English teaching process that was conducted twice in 95 minutes, interviewing the students and the lecturer related to teaching learning process and making transcript of interviews from twenty two of mechanical engineering students and lecturer. The steps of analyzing the data consist of three analysis, namely data collection, data display and drawing conclusion.

\section{Results}

The result of this research were devided three, they were interaction between lecturer and students, interaction between students and another students, interaction between students and learning material. 


\section{a. Interaction between lecturer and students}

This interaction between the lecturer and the students happened during all the teaching learning process. Classroom interaction in the mechanical engineering class was very communicative; all of the students responded to the lecturer's question. In an English classroom process, the interaction between lecturer and the students usually started when the lecturer greeted students in the beginning of teaching learning activities.

Lecturer : : Good morning students, how are you?

Students : Good morning, ma'am

(Observation \# 1)

The lecturer used English when she greeted the students.

Researcher : What language do you usually use in teaching, mam?

Lecturer $\quad$ : English, I usually use English in greeting students

(Interview transcript 8/page 4)

The lecturer also used English when she wanted to start the class. The lecturer usually asked the English learning materials that would be learnt.

Lecturer : Ok.. We continue the topic. Today, we study reading comprehension with the topic 'the first step of building'. Look at your copies!

Students : : Yes mam

Lecturer $\quad$ : Okay... The first sep of building. Haris, please read the text.

Student1 : Yes mam

(Observation \# 2)

Teaching reading materials between the lecturer and a student occurs when the lecturer asked a student to read and translate the text into Bahasa. By doing this, the lecturer wanted to improve the students' vocabulary. In giving question, the lecturer called random students's name. It was done to give opportunity to students in improving their English language. But sometimes the students could not answer the lecturer's question by their own words. They felt difficult to understand the text.

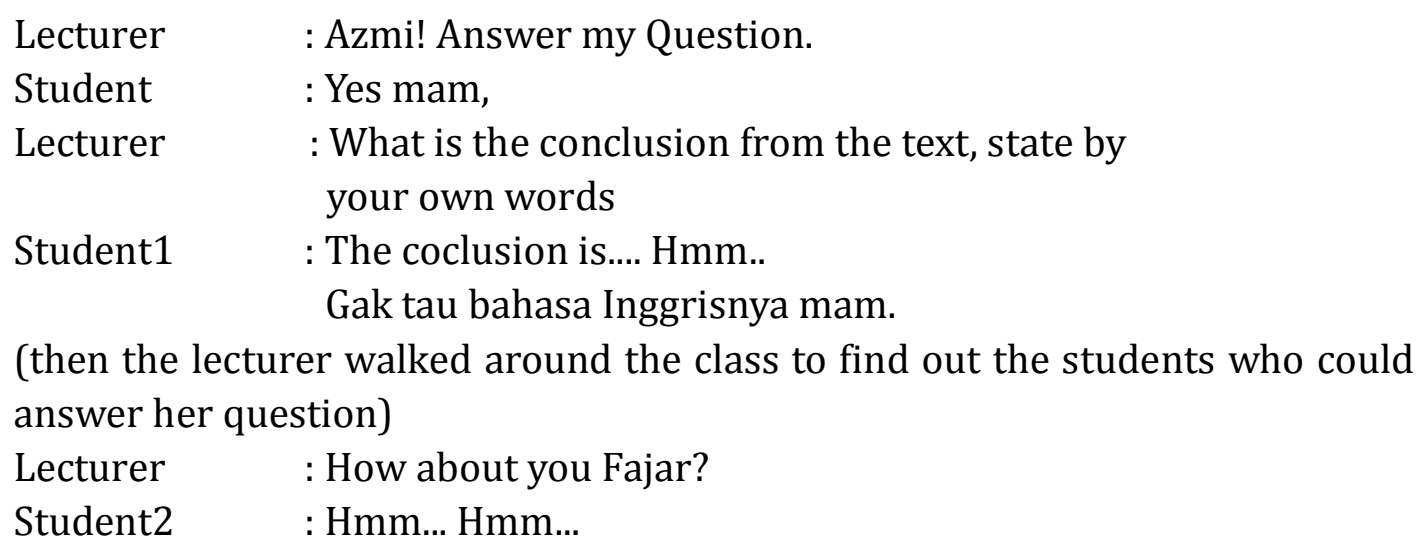


Lecturer $\quad$ : Come on, who can make conclusion from the text

(Observation \# 3)

Researcher : I observed you that you sometime walk around the class to get closer with the students.

Lecturer $\quad$ : Yes... I usually walk around the class when I want to improve the students's speaking. I want to stimulate them to be brave to share their ideas.

(Interview transcript 9/page 5)

Having finished giving question, lecturer walked around the class and close to each student to give interaction to the students. It was done to stimulate the students to be able to answer her question and to be brave to speak English.

\section{b. Interaction between student and another student}

The interaction between a student and another student occured in Bahasa. The interaction occured when the students were discussing about their learning material and experience to the others. In most cases, the students used more Bahasa than English.

$\begin{array}{ll}\text { Researcher } & \text { : If you want to ask the lesson that you } \\ & \text { don't understand with your friends, what } \\ & \text { language do you use? } \\ \text { Student } & \text { : I used Bahasa Indonesia } \\ \text { Researcher } & \text { : Why don't you use English? } \\ \text { Student } & \text { : I felt difficult to say it in English. It is easy to say } \\ & \text { it in Bahasa }\end{array}$

(Interview transcript 10/page 6)

They used English only when the lecturer asked them to have discussion for example, when they have conversation practices with the others about one topic in front of the class and answer the lecturer's question.

\section{c. Interaction between the student and the learning material.}

Interactions between the students and the lerning materials occured when the lecturer explained the materials and gave assignments to the students. When the lecturer explained the topic, the students should listened to her. And when the lecturer gave some tasks, they were very enthusiastic to do together with their group. When they were confused about the topic they usually asked to the lecturer.

Researcher : In explaining the material, your lecturer usually explans the lesson or writes in the whiteboard?

Student $\quad$ : The lecturer explains the lesson by using infocus and writes important point in the whiteboard.

Researcher : If the lecturer writes in thewhiteboard, do you write it in your book? Why? 
Dharmawati

Classroom Interaction In Teaching English For Mechanical Engineering Students

$\begin{array}{ll}\text { Student } & : \text { When I think it is important, I will write it. } \\ & \text { I will write it in my copies } \\ \text { Researcher } & : \text { Do you have learning material? } \\ \text { Student } & : \text { Yes, The lecturer shares the file of English } \\ & \text { learning material to print it. } \\ \text { Researcher } & \text { (Interview transcript 9/page 4) } \\ \text { Lecturer } & \begin{array}{l}: \text { : Yes... Of course. But I arranged my teaching material for } \\ \text { mechanical engineering students for many } \\ \end{array} \\ & \text { resources. I make it simple based on the syllabus } \\ & \text { and then I share to the students. }\end{array}$

(Interview transcript 11/page 5)

In teaching and learning process for mechanical engineering the lecturer had handbook but she used her own teaching material. She arranged the material and then share the file of her learning material to students, so they will print it. Every students must have learning materials.

\section{Discussion}

\section{a. Interaction between lecturer and students}

The interaction between the lecturer and the students in teaching English for mechanical engineering class also occurs in question and answer activities. The purpose of these was guiding the students to the topic of the lesson, getting the students' concentration from the beginning of the lesson, motivating the student during the class, expressing the students' mind verbally, reflecting the students' questioning and needs for further information, and encouraging the students to be critical thinking learners. Their responses to the lecturer could be expressed through their verbal and nonverbal languages. The verbal language could be expressed from their answers. Their nonverbal responses could be expressed from their behavior and seriousness during the class. When the lecturer asked some questions to the students, sometimes not all students give expected response. It happened because the students had less vocabulary and afraid to speak English. Rustandi and Mubarok (2017) declared that interaction in speaking subject at university level, students are less initiative to start the conversation because of shyness and reluctance. In the interaction the students looked difficult to respond the lecturer by using English. The percentage of using English in the interaction between the lecturer and students as can be shown in figure 4 below. 


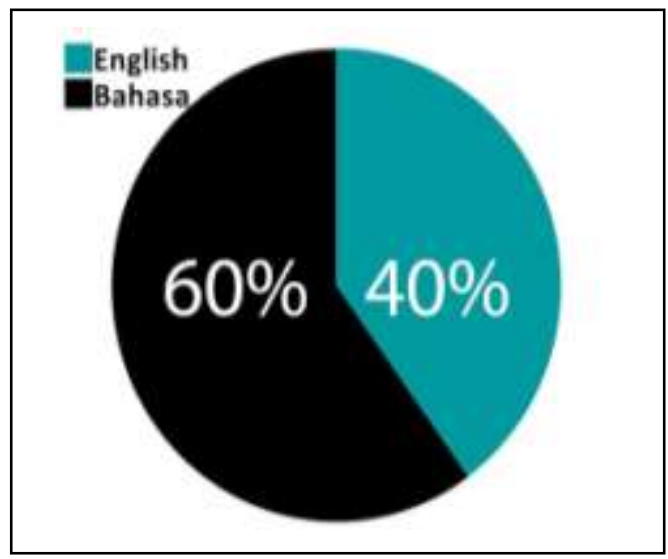

Figure 4. The Percentage of Using English in the Classroom Interaction

From figure above, it can be known that the classroom interaction between lecturer and students didn't use full English in teaching learning process, both lecturer and students used bahasa for $60 \%$ and the rest $40 \%$ they used English. Actually the lecturer didn't fell difficulty in managing the class. Because the students paid attention in learning English. But it was hard for the students to understand English well. From the observation, it happened because the students had limited vocabulary and they also were afraid to make mistake when they spoke English. . It conclude that the dominant types of interaction in teaching English for mechanical engineering students was teacher - student interaction.

\section{b. Interaction between student and another student}

The interaction between a student and another student happens in the classroom use Bahasa. The interaction occured when the students were chatting or telling about their experience to the others. In most cases, the students used Bahasa or Batak language. They were shy if the words they used were false when they were speaking English. They used English only when the lecturer gave some tasks that needed the use of English. For example, in conversation that practices with the others in front of the class.

\section{c. Interaction between the student and the learning material.}

Interaction occured between the students and the learning materials when the lecturer explained the learning materials and when the lecturer gave quiz and assignments to the students. When the lecturer explained the learning material, the students should write it in the white board or their copies. If the lecturer asked them some tasks, they were very enthusiastic to do that. If they were confused about the learning material they usually asked to the lecturer. The students have learning materials given by the lecturer. 


\section{Conclusion}

The classroom interactions occured in the English teaching and learning process in mechanical engineering class are interaction between lecturer and students, interaction between a student and anoter student, and interaction between the student and the learning materials. The dominant classroom interaction in teaching and learning process for mechanical engineering class at Universitas Harapan Medan was between the teacher and students. The percentage of using English in the interaction between the lecturer and students in the classroom is $40 \%$. It happened because the students had difficult to respon the lecturer's question in English. It conclude that the dominant types of interaction in teaching English for mechanical engineering students was teacher-student interaction.

\section{Acknowledgement}

The writer thanks goes to Mr. Abdul Jabbar Lubis, ST, M.Kom as the dean of Universitas Harapan Medan who has supported and motivated this research. Thanks also to colleagues, and kind students who have helped complete this research, so that this research can be completed on time

\section{References}

Allwright, D. and Bailey, K. M. (1991) Focus on the Language Classroom: An Introdution to Classroom Research for Language Teachers. New York: Cambridge University Press.

Andi, Sudirman Mangnguntungi. (2018) The Application Of Politeness Strategies Among Teacher And Students In Classroom Interaction At Sma 1 Pamboang, Majene. IDEAS: Journal on English Language Teaching and Learning, Linguistics and Literature, [S.l.], v. 6, n. 1, ISSN 2548-4192

Dosma M.P. (2017) An analysis Classroom Interaction in English Subject At Senior High School. Genre Jurnal. Volume 2 No.1 2017.

Fibri, Lisanty AD Indira. (2018) Classroom Interaction Patterns In Efl Classroom At Jakarta Intensive Learning Centre (Jilc). IDEAS: Journal on English Language Teaching and Learning, Linguistics and Literature, [S.l.], v. 6, n. 2, ISSN 2548-4192.

Goronga, P. (2013) The Nature and Quality of Classroom Verbal Interaction: Implications For Primary School Teachers In Zimbabwe. Academic Research International, University of Zimbabwe, Zimbabwe.

Mayer, Kutz. (2006) Mechanical Engineers' Handbook Third Edition: Manufacturing and Management. John Wiley \& Sons, Inc., Hoboken, New Jersey.

Muhammad Ansory, Nahar N. (2018) English Teachers' Perceived Benefits And Challenges Of Flipped Classroom Implementation. Journal of Education and Linguistics Studies (JEELS), 211-227

Permendikbud (2016) Nomor 23 Tahun 2016 Tentang Standar Penilaian 
IDEAS, Vol. 8, No. 1, June 2020

ISSN 2338-4778 (Print) ISSN 2548-4192 (Online)

Pendididkan.

Rini, T,P. (2013) Classroom Interaction: An Analysis Of Teacher Talk And Student Talk In English For Young Learners (Eyl). Journal on English Education, Vol 1, No 1.

Rohim, F. (2015) Materi Pelatihan Guru Implementasi Kurikulum 2013 Jenjang SMA/SMK Tahun 2015: Mata Pelajaran Bahasa Inggris. Kementrian Pendidikan dan Kebudayaan.

Rustandi, A., \& Mubarok, A. H. (2017) Analysis of IRF (Initiation-Respon-Feedback) on classroom interaction in EFL speaking class. Edulite: Journal of English Education, Literature, and Culture, 2(1), 239-250. 